\title{
Mochras borehole revisited: a new global standard for Early Jurassic earth history
}

\author{
S. P. Hesselbo ${ }^{1}$, C. J. Bjerrum ${ }^{2}$, L. A. Hinnov ${ }^{3}$, C. MacNiocaill ${ }^{4}$, K. G. Miller ${ }^{5}$, J. B. Riding ${ }^{6}$, \\ B. van de Schootbrugge ${ }^{7}$, and the Mochras Revisited Science Team \\ ${ }^{1}$ Camborne School of Mines, College of Engineering, Mathematics and Physical Sciences, \\ University of Exeter, Penryn Campus, Treliever Road, Penryn, Cornwall, TR10 9EZ, UK \\ ${ }^{2}$ Geology Section, Department of Geosciences and Natural Resource Management, University of Copenhagen, \\ Øster Voldgade 10, 1350 Kbh. K., Denmark \\ ${ }^{3}$ Department of Earth and Planetary Sciences, Johns Hopkins University, Baltimore, MD 21218, USA \\ ${ }^{4}$ Department of Earth Sciences, University of Oxford, South Parks Road, Oxford, OX1 3AN, UK \\ ${ }^{5}$ Department of Earth \& Planetary Sciences, Rutgers, The State University of New Jersey, \\ 610 Taylor Rd., Piscataway, NJ 08854-8066, USA \\ ${ }^{6}$ British Geological Survey, Keyworth, Nottingham NG12 5GG, UK \\ ${ }^{7}$ Institute of Earth Sciences, University of Utrecht, Budapestlaan 4, 3584 CD Utrecht, the Netherlands \\ Correspondence to: S. P. Hesselbo (s.p.hesselbo@exeter.ac.uk)
}

Received: 17 July 2013 - Revised: 4 October 2013 - Accepted: 11 October 2013 - Published: 5 November 2013

\section{Introduction}

The Early Jurassic epoch was a time of extreme environmental change: there are well-documented examples of rapid transitions from cold, or even glacial, climates to super greenhouse events, the latter characterized worldwide by hugely enhanced organic carbon burial, multiple large isotopic anomalies, global sea-level change, and mass extinction (Price, 1999; Hesselbo et al., 2000; Jenkyns, 2010; Korte and Hesselbo, 2011). These icehouse-greenhouse events not only reflect changes in the global climate system but are also thought to have had significant influence on the evolution of Jurassic marine biota (e.g. van de Schootbrugge et al., 2005; Fraguas et al., 2012). Furthermore, the events may serve as analogues for present-day and future environmental transitions.

Although our knowledge of specific global change events within the Early Jurassic is rapidly improving, such as the Toarcian oceanic anoxic event (or T-OAE), we still do not have a comprehensive understanding of the timing, pacing, or triggers for these environmental perturbations, principally because of the temporally fragmentary nature of the existing data sets. The major goal for this proposed ICDP project is therefore to produce a new global standard for these key 25 million years of earth history by re-drilling and double- coring a $45 \mathrm{yr}$ old borehole at Mochras Farm on the edge of Cardigan Bay, Wales, and developing an integrated stratigraphy for the cored material. The new data sets will be applied to understand fundamental questions about the longand short-term evolution of the earth system. Cycles that occur regionally and that provisionally appear in the Mochras logs will allow evaluation of the extent to which major environmental change events are astronomically forced, resulting from internal system dynamics, or are triggered by deepearth processes.

\section{The first Mochras borehole}

The original "Llanbedr (Mochras Farm)" borehole was drilled on the coast of West Wales from 1967 to 1969 (Figs. 1 and 2). Contrary to expectations, a biostratigraphically complete succession of marine mudstone of Early Jurassic age was recovered with a thickness of $1300 \mathrm{~m}$, some $600-1900 \mathrm{~m}$ below surface (Woodland, 1971; Dobson and Whittington, 1987; Figs. 3 and 4). This is approximately three times the thickness of the same age strata known from other UK boreholes or from the internationally important coastal exposures. The Mochras succession is also remarkable for the relative uniformity of argillaceous lithology, and the biostratigraphy is relatively well known. Although the borehole succession 

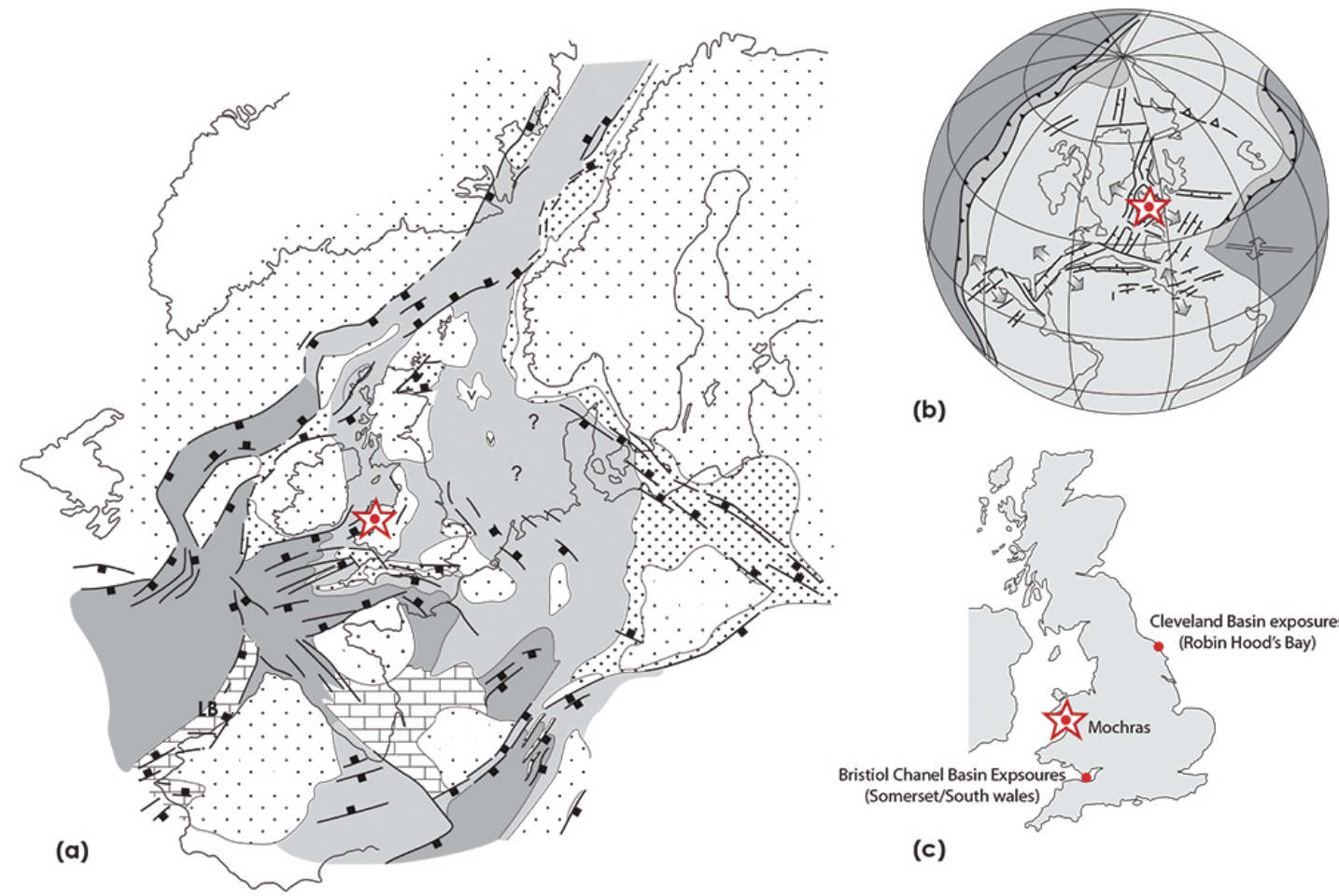

(b)

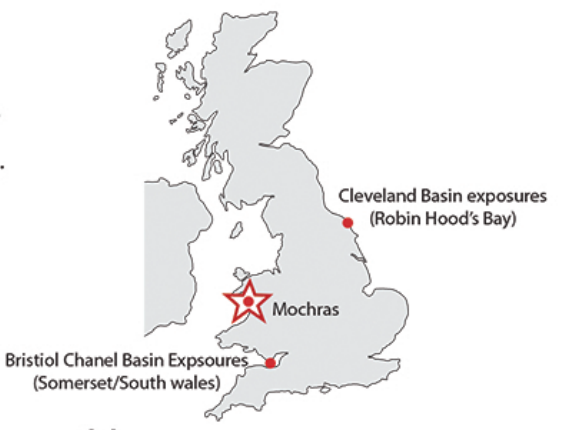

(c)
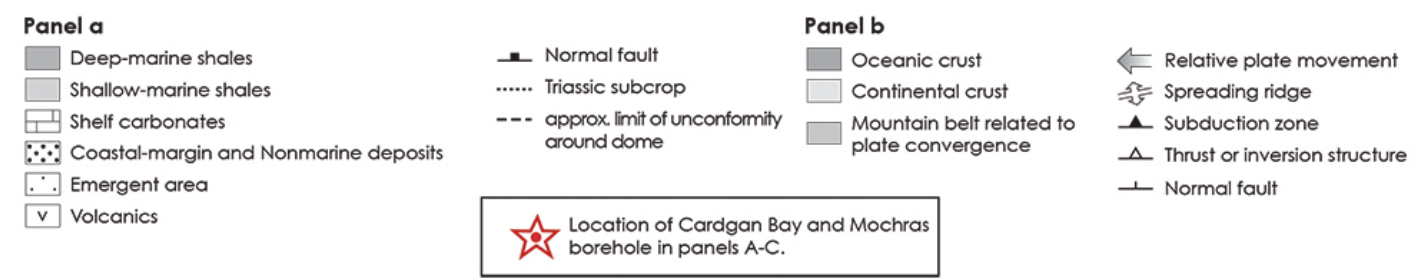

Figure 1. Palaeogeographic setting of the first Mochras borehole (modified from Coward et al., 2003).

has figured prominently in discussions of regional Jurassic palaeogeography and basin development (Holford et al., 2005), drilling predated modern drilling and logging techniques and the advent of chemostratigraphy and cyclostratigraphy, and as a result the true potential of this section to shed light on global processes and history has never been realized. The existing log suite comprises only total gamma ray, spontaneous potential, resistivity (laterolog), neutron, density, and sonic, and these logs were run to a limited depth of $1300 \mathrm{~m}$ (or down only to mid-Sinemurian strata). There are no $\operatorname{logs}$ for the Hettangian and early Sinemurian stages and very sparse log data for the Toarcian (see Fig. 3).

\section{Workshop participants and programme}

Recognizing the potential for realizing a transformative understanding of climate changes between extremes, the ICDP funded a workshop to plan future drilling at Mochras. The workshop participants comprised thirty-two researchers from China, Denmark, France, Germany, Hungary, the Nether- lands, Poland, Switzerland, the UK and the USA. These participants also represented the wider interests of another ten scientists who have expressed an interest in the project but were unable to attend the meeting, including colleagues from Argentina. The workshop was held from 16 to 23 March and comprised a field excursion to the Cleveland Basin, core viewing at the British Geological Survey core store at Keyworth, Nottingham, two days of discussion in Oxford, and a supplementary field excursion to the Bristol Channel basin.

\section{Field excursions}

The field excursion to the Cleveland Basin, Yorkshire (Fig. 1), provided an opportunity to inspect the closest available outcrop analogue for the succession of late Sinemurian to late Toarcian age at Mochras, albeit in a much thinner and more sand-rich succession. Additionally, the Yorkshire coastal exposures include classic exposures of the Jet Rock, the archetypical expression of the Toarcian oceanic anoxic event in NW Europe. 


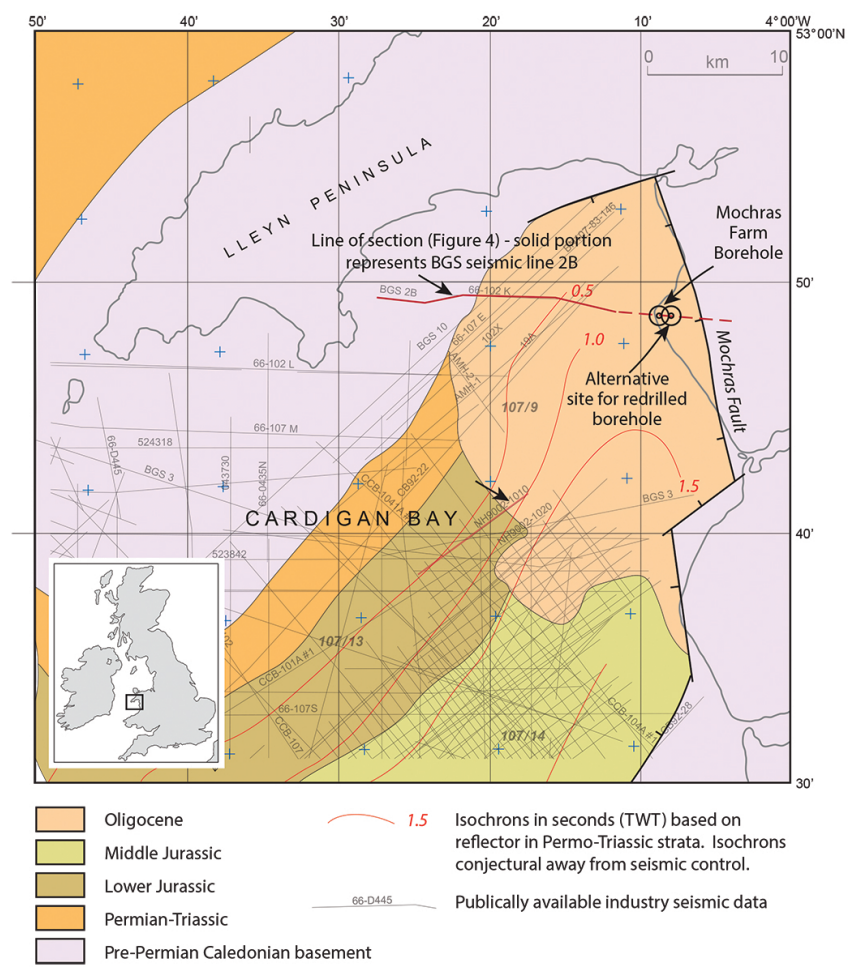

Figure 2. Simplified offshore and onshore geological map for the Cardigan Bay area showing existing and alternative borehole sites together with publically available seismic reflection survey data (based on Dobson and Whittington, 1987; Tappin et al., 1994; British Geological Survey 1:25000 map of Cardigan Bay, Solid Geology).

The first day of the field programme began with an overview of the depositional setting, and then focussed on the late Sinemurian to early Pliensbachian succession of Robin Hood's Bay whilst the second day concentrated on the Pliensbachian-Toarcian transition at Staithes and Port Mulgrave. The party inspected a large normal fault in the southern end of Robin Hoods bay with about $300 \mathrm{~m}$ of throw. Remarkably little deformation of the shale successions is present $10 \mathrm{~m}$ from the fault.

In Robin Hood's Bay, two putatively global black shale "events" are exposed in the section, the older around the Oxynoticeras oxynotum ammonite zone, and the younger at the Sinemurian-Pliensbachian boundary. Both events are expressed in significant faunal or floral changes and perturbations of the global carbon cycle (Korte and Hesselbo, 2011; Riding et al., 2013) and the Robin Hood Bay section serves as the Global Stratotype Section and Point (GSSP) for the base of the Pliensbachian Stage (Meister et al., 2006; Fig. 5a). Although the Robin Hood's Bay section represents one of the best-characterized successions in the world for the stage boundary, it is notable that the basal ammonite biozone of the Pliensbachian in Mochras is double the thickness of the same zone in Robin Hood's Bay, emphasising the global importance of additional sampling of the Mochras succession.

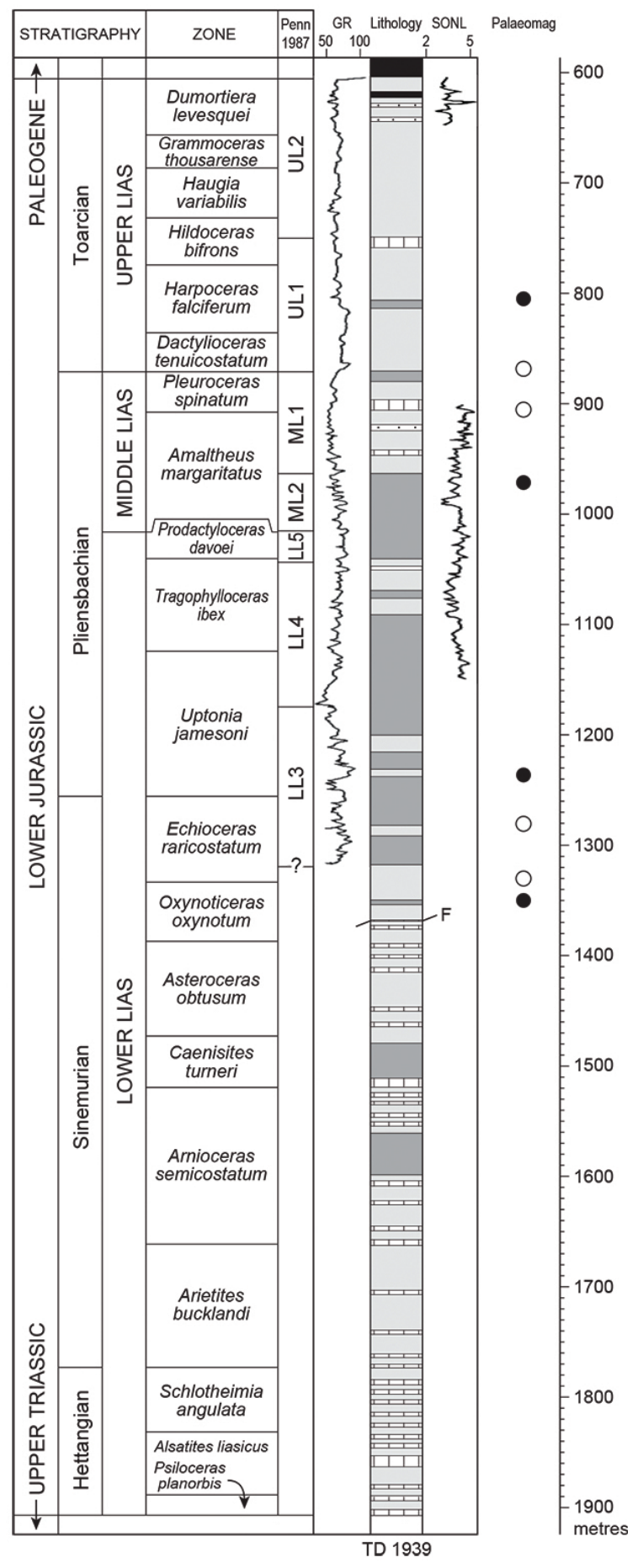

Figure 3. Summary stratigraphy for the first Mochras borehole showing complete representation of Early Jurassic ammonite zones (modified from Tappin et al., 1994). Also indicated are the palaeomagnetic polarities from pilot studies of MacNiocaill and Robinson (unpublished data). Lithology: black - conglomerate, grey silt/mudstone, light grey mudstone, dots - sandstone, bricks, limestone, TD - terminal depth, F - fault, GR - gamma-ray log, SONL sonic log, black dot - normal polarity, white dot - reversed polarity. 


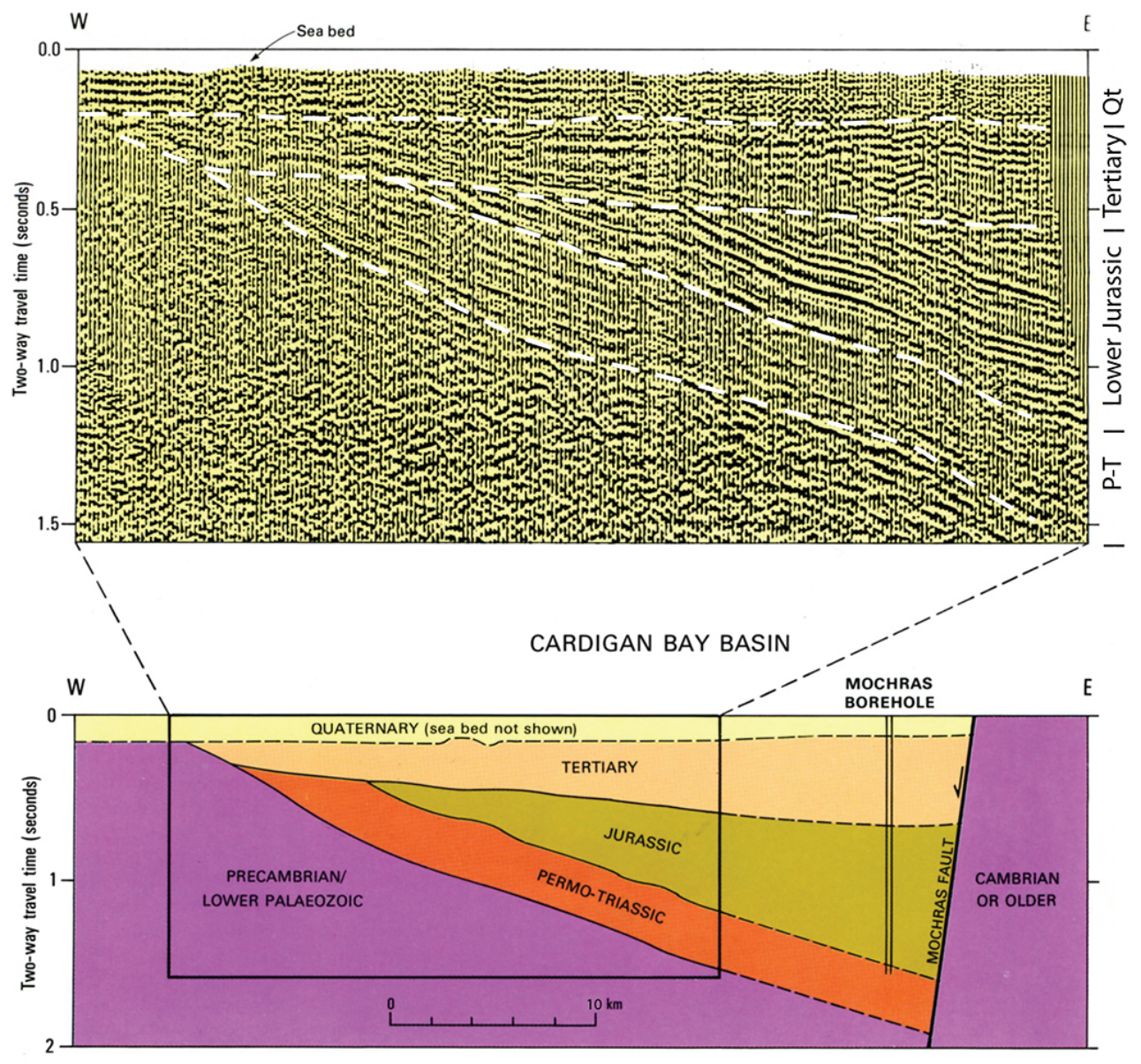

Figure 4. British Geological Survey seismic reflection profile 2B and extended geological interpretation including original Mochras borehole (from Tappin et al., 1994, with minor modification).

A prime research goal for the Mochras project is the construction of a robust astrochronology for the entire Early Jurassic. The field excursion allowed discussion of previous cyclostratigraphic studies based on stratigraphically limited intervals of the Cleveland Basin succession. In particular the early Pliensbachian interval has been a target for earlier attempts to recognize regular cycles (Van Buchem et al., 1994); the same interval has been shown to be regularly cyclic in widely spaced UK outcrops and in the Mochras core (Weedon and Jenkyns, 1999; R. Morgan, unpublished student project, Oxford). Additionally, other intervals exposed in the Yorkshire cliffs, such as the mid-Sinemurian interval, appear to be regularly cyclic, but have never been systematically studied (Fig. 5b).

Methane seep mounds have been described recently from several Early Jurassic mudrock successions worldwide and have been shown to have a distinctive carbon-isotopic signature (e.g. Allison et al., 2008; van de Schootbrugge et al., 2010). The field party made a serendipitous discovery of previously undescribed methane seep carbonates in the interval above the Jet Rock at the southern end of Robin Hood's
Bay (Fig. 5c). The impact of coeval methane seeps on local carbon-isotope signatures is an important topic to explore as there is a potential impact on use of carbon-isotope time series for cyclostratigraphic analysis and global correlation.

The transition from shallow-water and generally coldclimate sandstone and ironstone of the late Pliensbachian into the deep-water super-greenhouse organic-rich shale of the TOAE is exposed around Port Mulgrave (Fig. 5d). This part of the succession in Yorkshire is also half the thickness and stratigraphically less complete than the equivalent succession at Mochras. Very large excursions occur in all isotopic systems previously investigated across the T-OAE, and the party discussed the most recent data from systems that respond to local, regional and global changes in ocean redox conditions (e.g. Pearce et al., 2008; Gill et al., 2011). Also clear from the field excursion was cyclicity expressed in lithofacies and ichnofacies, which provides an immense wealth of data for palaeoenvironmental interpretations.

The supplementary field excursion to the Bristol Channel Basin in west Somerset (Fig. 1) examined the carbonaterich marine mudstone facies of the Blue Lias Formation, 

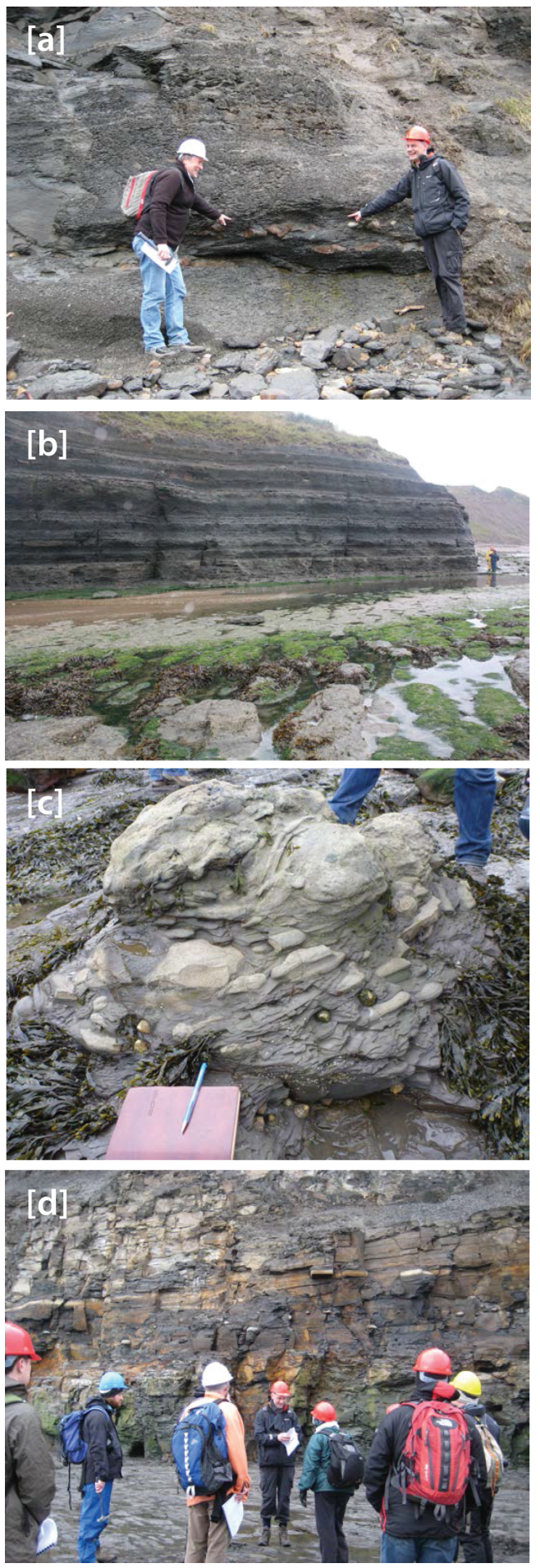

Figure 5. Highlights of the Cleveland Basin field excursion, Yorkshire. (a) GSSP for the base of the Pliensbachian Stage (Robin Hood's Bay). (b) Potentially regularly cyclic late-Sinemurian succession (Robin Hood's Bay). (c) Probable methane seep carbonate mound and concretions in early Toarcian strata (Robin Hood's Bay). (d) Exposure of the Jet Rock (record of the Toarcian OAE) at Port Mulgrave. including the record of the Late Triassic mass extinction at St Audries Bay, and the base-Sinemurian GSSP at Kilve. Also discussed was the potential of this facies, closely similar to that of the same age in the first Mochras borehole, to yield a continuous astrochronology, as previously documented by Ruhl et al. (2010).

\section{Core viewing}

Core from the first Mochras borehole was laid out for inspection and sampling at the British Geological Survey core store at Keyworth, Nottingham. In particular the party focussed on major environmental change events and/or stage boundaries. As well as visual description, it was possible to take samples for geochemical pilot studies. Because the core is over forty years old, oxidation of reduced phases during storage is a significant impediment to some geochemical analyses, notably analyses dealing with sulfur isotopes. Nevertheless, samples were obtained to generate pilot data sets for various geochemical techniques to document the fidelity of the section for detailed studies in the proposed core hole. The palaeontological collections were inspected and latex casts taken of the key fossils for more precise identification. The original core had been extensively broken for palaeontological sampling soon after drilling, and the resulting fragments aggregated into stratigraphically crude intervals ranging up to about half a metre. On the other hand, some core that had been previously thought to be missing was rediscovered, such as some early Hettangian strata and including core across the Triassic-Jurassic boundary. In all some 200 samples were collected for further work. In addition, the downhole log paper plots were scanned at high resolution and will be digitized for cyclostratigraphic analysis.

Visual inspection of the core shows that diverse and variable trace fossil assemblages and lithofacies are present, allowing sophisticated interpretations of palaeoenvironmental change to be made through the entire cored interval. Combined with palaeoecological analysis, the Mochras core clearly has the potential to yield an extended record of sealevel change.

\section{Oxford workshop}

The Oxford workshop initially tackled the first-order science questions that would be addressed by drilling the new core hole, and then went on to consider the data sets required to meet these science goals and the practical challenges to be overcome. Overview presentations provided the logistical and theoretical background for project planning.

The workshop endorsed the view that a new Mochras core will give an exceptionally continuous record of environmental change (broadly defined), combined with an unrivalled integrated timescale. This combination will provide unparalleled opportunity for quantitative understanding of the evolution of the earth system and its relationship to 


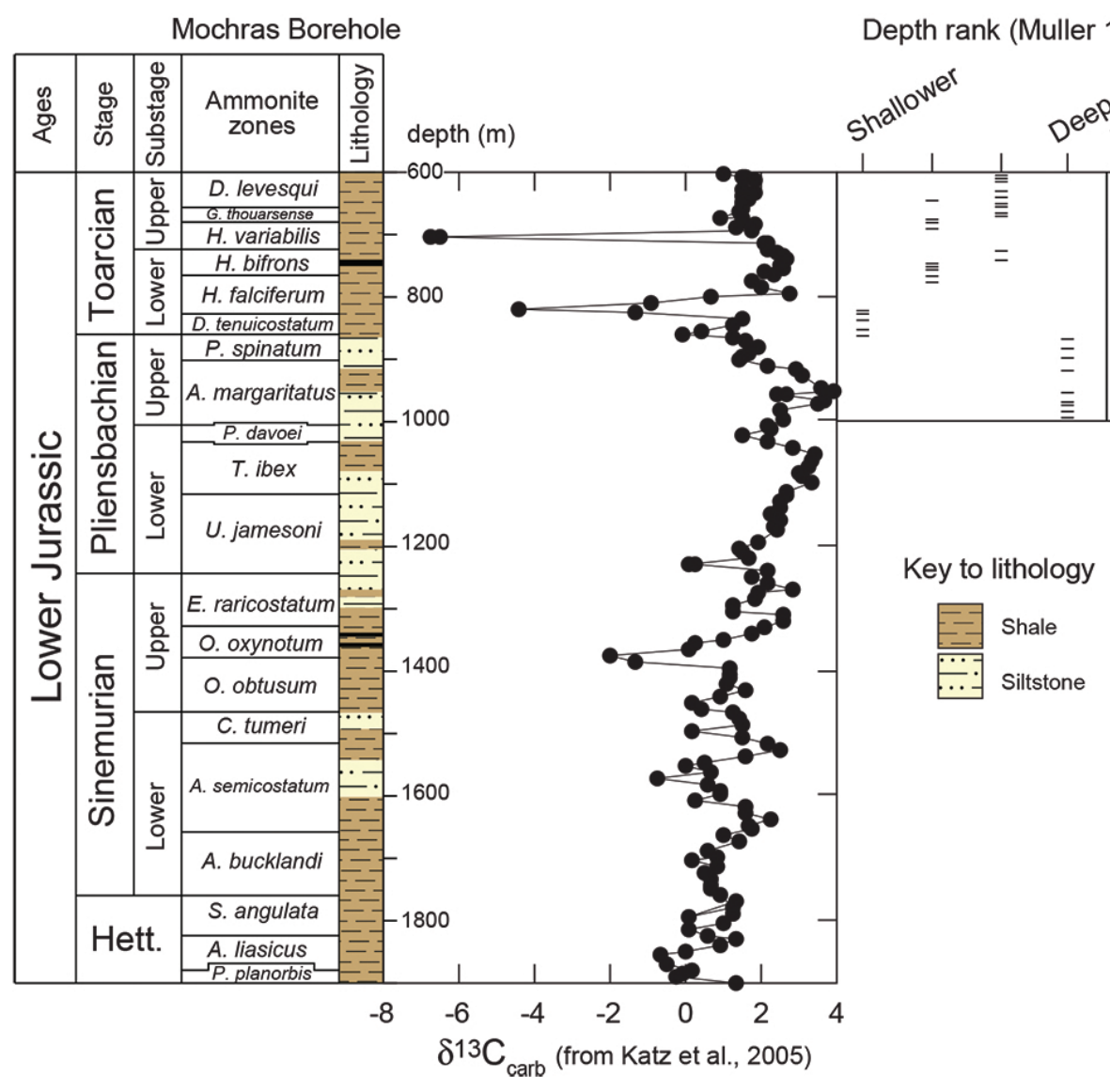

Figure 6. Carbon-isotope profile from bulk carbonate and palaeodepth changes inferred from benthic foraminifers. Modified after van de Schootbrugge et al. (2005). Hett. = Hettangian.

solar system evolution at the point of emergence into the modern world.

Mochras has the potential to provide a global template for Early Jurassic earth systems interaction, an interval of major tectonic change (e.g. supercontinent breakup and formation of the Central Atlantic Magmatic Province or CAMP, one of the largest large igneous provinces), biologic change (e.g. radiation of eukaryotic phytoplankon), and climate change (e.g. the transition from an icehouse to a super greenhouse associated with a major oceanic anoxic event). Such a complete profile with high-resolution stratigraphic framework will provide an invaluable template for correlation of other profiles of that age, including those representing marginalmarine and non-marine facies. Chemostratigraphy and astrochronology should provide a useful tool for such correlation, linking oceanic and atmospheric systems of that time (e.g. Hesselbo and Pienkowski, 2011).

The following science programme was developed at the workshop:

Chemostratigraphy. As demonstrated on the field excursion, several major environmental change events in the Early Jurassic have been documented recently, but are largely unexplored scientifically; some are associated with carbon- isotope anomalies at least as large as that associated with the Paleocene-Eocene boundary (Korte and Hesselbo, 2011; Riding et al., 2013). The Sinemurian-Pliensbachian boundary event is a good example, and shows characteristics akin to the T-OAE, such as increased carbon burial and significant sea-level rise. A crucial requirement for chemostratigraphy - and for the use of geochemical proxies generally - is the preservation of a substrate from which the original chemical attributes of the environment can be extracted and which lack strong diagenetic overprint. Importantly, comparison of the well-characterized carbon-isotope data set from Yorkshire with the low-resolution carbon-isotope data from the original Mochras core, shows that the values in moderately low-maturity organic matter from Mochras $\left(R_{0} \max =0.38\right.$ 0.63 ; Holford et al., 2005) track changes in the global carbon cycle (Korte and Hesselbo, 2011; van de Schootbrugge et al., 2005; Fig. 6). Thus, a re-drilled Mochras core has the strong potential to provide a global standard high-resolution carbon-isotope stratigraphy for the entire Early Jurassic interval based on marine and nonmarine organic matter and also likely carbonate.

Palaeobiology and palaeoecology. Detailed records of macro- and microfossils can be generated at metre-scale 
resolution. An understanding of biotic change through the Early Jurassic is possible based on combined analysis of the taxonomy and paleoecology of molluscs (including ammonites), dinoflagellates, pollen, calcareous nannofossils, benthic foraminiferas and ostracods. These data will also form the foundation for the high-resolution biostratigraphic framework required for timescale development and for application of the broad array of results from Mochras to other parts of the world. Benthic foraminiferas and ostracods, previously studied from the first borehole (Johnson, 1975, 1976; Copestake and Johnson, 1984; Boomer and Whatley, 1992), can be used both as ecological indicators of environmental change, and as paleobathymetric indicators of sea level change. Phytoplankton (dinoflagellate cyst and nannofossil) data are essential for describing the early radiation of these groups, and for understanding mechanistic links between primary production and carbon cycling, especially during carbon cycle perturbations such as the T-OAE. Pollen records will document terrestrial floral changes in the aftermath of the end-Triassic mass-extinction, and can be used to reconstruct continental floral changes during times of deoxygenation in the oceans, and will ground-truth records of charcoal delivered to the oceans from forest fire burning.

Macrofossil analysis is possible in core material because of the small size and/or abundance of benthic molluscs during the Early Jurassic, as has been proven in the contemporary Schandelah core, recently drilled in northern Germany. Studies on well-preserved macroscopic ichnofabric will provide important "in situ" data, reflecting changing environmental conditions on the bottom such as food supply, redox, water depth, and sea-level change. Biotic records can also be compared with records of nutrient regime and redox to elucidate the processes driving faunal change.

Astrochronology. Also of marked importance is the potential of Mochras to yield an astrochronology for the time represented by the Early Jurassic, where existing records are fragmentary and of limited time extent. Work on research boreholes drilled through a $500 \mathrm{~m}$ thick Late Jurassic mudstone succession in southern England (Kimmeridge Clay) have previously yielded an astrochronological calibration of unprecedented detail, which has been used to define the durations of sea-level cycles and help to calibrate the Kimmeridgian-Tithonian timescale (Huang et al., 2010). New data from a re-drilled Mochras borehole will allow the establishment of a cyclostratigraphic age model that will close the gaps between the older cyclostratigraphies (Olsen and Kent, 1999; Ruhl et al., 2010) and the younger parts of the geological column. The combination of high-resolution chemostratigraphy and astrochronology will provide fundamental insights into the pacing of changes in the mid-Mesozoic carbon cycle, including those occurring during the big environmental change events, and thus help identify their ultimate causes. Pilot cyclostratigraphic studies based on the old geophysical logs were presented or discussed at the workshop (L. Hinnov, C. Huang, R. Morgan,
T. Wonik; Fig. 7). Mochras will provide a $25 \mathrm{Myr}$ record of astronomically tuned earth history that in addition to eccentricity and precession includes also the obliquity signal, potentially giving a unique opportunity to test astronomical models of Earth-Mars resonance in deep time. As well as providing an order of magnitude improvement in precision and accuracy of the geological timescale for the Early Jurassic, we can use new Mochras data to test astronomical pacing of icehouse and greenhouse sea level changes in the Mesozoic world.

Magnetostratigraphy. The new core will have great potential for definition of a magnetostratigraphy for the Early Jurassic interval. An accurate magnetostratigraphy is particularly important because it enables correlation not only to marine but also to terrestrial successions, which facilitates the global use of the newly developed Early Jurassic standard in the redrilled Mochras borehole. Although palaeomagnetic studies were undertaken at the time of the original drilling (Woodland, 1971), the sensitivity of modern instruments is now better by a factor of 100 . Thus new (oriented) cores have the potential to provide a robust and complete reference magnetostratigraphy calibrated by astrochronology. A pilot study based on the existing core has also yielded very promising results (Fig. 3).

Geochronology and age model. The biostratigraphy, chemostratigraphy, cyclostratigraphy and magnetostratigraphy need to be anchored in an absolute chronological framework. The approach developed will be to construct an integrated age model for the time interval of interest, comprising radio-isotopic dating (U-Pb zircon by ID-TIMS) of stratigraphic sections in Canada and South America; sections that are already well-constrained biostratigraphically and with rapidly improving chemostratigraphy. Quantitative methods should be used for stratigraphic correlation and seriation, e.g. Constrained Optimization/CONOP9, and algorithms for objectively combining the radio-isotopic dates into a high-precision and high-accuracy age model (Sadler et al., 2003; Meyers et al., 2012). The recent EARTHTIME initiative has meant that the U-Pb system is now fully calibrated to standard units and capable of producing dates with uncertainties of the order of $0.15 \%$ (95\% confidence, including ${ }^{238} \mathrm{U}$ decay constant error). This is more than sufficient to resolve the $405 \mathrm{kyr}$ eccentricity band width, and thus the radio-isotopic dating can be used to pin down the floating highly-resolved astrochronology. This absolute chronology will be required to assess the exact temporal relationship of documented environmental perturbations to driving mechanisms (e.g. emplacement of the Karoo LIP at about $183 \mathrm{Ma}$; Svensen et al., 2012).

Atmospheric composition. Carbon dioxide and oxygen levels in earth's atmosphere are controlled by biogeochemical feedbacks that take place on million-year timescales. The major disruptions to earth's carbon cycle represented by OAEs are believed to have interfered with the oxygen content of the atmosphere (Handoh and Lenton, 2003). Forest 

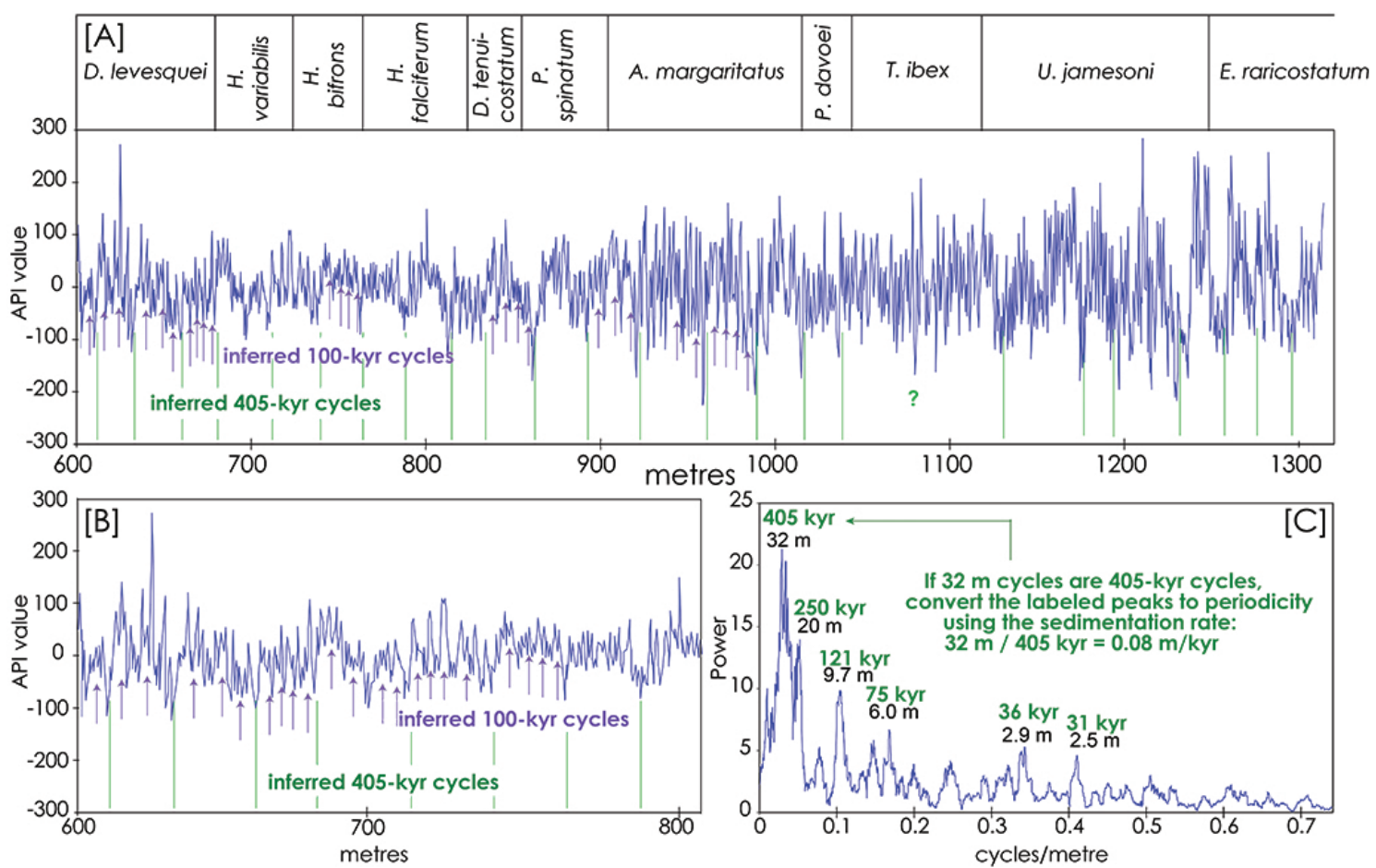

Figure 7. Gamma ray log from the original Mochras borehole, digitized from original analog graphs. (a) Entire series after removing a longterm irregular trend. (b) Interval from the upper part of the borehole highlighting $\sim 32 \mathrm{~m}$ cycling interpreted as $405 \mathrm{kyr}$ cycles, (green) and 6-9.7 m cycles interpreted as $\sim 100 \mathrm{kyr}$ cycles (purple). (c) Multitaper power spectrum of the entire gamma-ray log series and preliminary Milankovitch interpretation.

fires require oxygen in order to burn, meaning that forest fire activity is highly sensitive to variations in the abundance of oxygen in the atmosphere (Belcher and McElwain, 2008). There is therefore a record of palaeoatmospheric oxygen in the form of fossil charcoal, which can be used to reconstruct changes in atmospheric oxygen content through this interval, when all existing hypotheses predict that there should have been huge changes.

Seawater oxygenation and nutrient flux. There are many new palaeoceanographic proxies now available specifically for organic-rich and organic bearing mudstones, these include: Mo, Cr, U isotopes for determination of globalregional extent of anoxia; redox-sensitive and $\mathrm{pH}$-sensitive trace metals $\mathrm{U}$, Mo, etc.; highly reactive $\mathrm{Fe}$, and; compoundspecific biomarker analysis (e.g. Anbar and Gordon, 2008; McArthur et al., 2008; Pancost and Boot, 2004). These new and developing proxies (e.g. Poulton and Canfield, 2005, 2006) can be applied in conjunction with pyrite petrography (Wignall and Newton, 1998) and SEM, thin section and micro-CT to evaluate the severity and timescales of euxinia $\left(\mathrm{H}_{2} \mathrm{~S}\right)$. Isotopic analyses of pyrite and carbonate-associated sulfur (CAS) can provide important constraints on regional or global changes in the pyrite burial flux and the operation of the oxidative pathway of the sulfur cycle (e.g. Newton et al., 2004, 2011; Gill et al., 2011). These redox studies can then be used to constrain controls on nutrient recy- cling, thus providing insights into nutrient-redox feedbacks (März et al., 2008). Biomarker records of photic zone euxinia and pyrolitic processes will be used to constrain anoxia in the water column and oxygen concentrations in the atmosphere, respectively. Fresh core material is key to obtain high-resolution inorganic and organic geochemical proxy records.

Palaeoceanography. Palaeogeographically, the location of Mochras is at a critical latitude, influenced both by subtropical and mid-latitude climate and oceanography, and thus very susceptible to astronomical forcing (Ruhl et al., 2010; Bjerrum et al., 2001). At the same time, the transcontinental seaway, linking Tethys to the Boreal Ocean would have strongly influenced the regional oceanography. Currently there is considerable interest in the hydrocarbon industry for understanding palaeoconditions at high northern latitude (source rocks, as well as weathering and climate influence on the development of sand reservoirs). The location of Mochras potentially provides a means to connect our understanding of palaeoceanographic processes on the southern and northern margins of the transcontinental seaway.

Of some significance is better evaluation and understanding of sea-level changes, based partly on a sequence stratigraphic correlation to other profiles representing a variety of facies and environments (Hesselbo and Jenkyns, 1998; Pieńkowski, 2004; Korte and Hesselbo, 2011). Information 
on sediment provenance and hinterland climate may be extracted from study of detrital clay minerals (e.g. Hesselbo et al., 2009). Clay mineralogy has been successfully used in many Mesozoic palaeoclimate reconstructions, especially as reliable proxy for humidity (Dera et al., 2009). Besides, highresolution clay mineral analyses will provide another proxy for inferring astronomically forced climate cycles. Electronbeam-based techniques applicable to mudrocks can be used to infer changes in both sea level and climate (improving hugely on early work such as Williams et al., 2001).

Earth system models. The nature of the changes in the carbon, oxygen and nutrient cycles through the Toarcian oceanic anoxic event and adjacent intervals will be a major focus of study. In particular the combination of models, such as those of Bjerrum et al. (2006) and Bjerrum and Canfield (2011), and data from Mochras can be used to test the hypothesis that organic carbon burial during the event caused a rise in atmospheric oxygen that ultimately ended the OAE (Handoh and Lenton, 2003). Associated with this is the idea that transitions between oxic and anoxic states of the ocean are propelled by positive feedback involving phosphorus burial/recycling - recycling is enhanced under anoxic conditions, suppressed under oxygenated conditions.

\section{Borehole location and logistical considerations}

A detailed coring, logging, and sampling plan was articulated at the Oxford workshop. The core hole will be drilled between the period of October 2015-March 2016 with a large diameter $(38-10 \mathrm{~cm})$ core and 9-10 logging runs. The location of the original borehole, adjacent to a now disused military aircraft facility (Fig. 8), means that deployment of the drilling rig will be relatively straightforward. The favoured precise location of the new hole is still subject to the results of geophysical site survey, but the provisional plan is to locate the new hole a few hundred metres inland of the original borehole site, but with a significant slant to avoid fault-related disturbance at depth. A slanted core may also facilitate accurate core reorientation.

Onsite descriptions will consist of minimal measurements (onsite photos, general lithology, grain size, sorting, roundness, bedding, colour, fossil content, ichnofabric, physical structures, cement, accessory minerals, contacts). Cores will be transported to the British Geological Society (BGS) core repository where they will be split into thirds (archive, working, and macrofossil) and scanned (Geotek, XRF, and photoscans). A detailed core description and sampling party (lasting approximately 1 month) of all participants will be held about 6 months after drilling. We anticipate a similar number of samples as that obtained from a typical IODP succession of similar thickness ( 10000 samples). The core will be archived at the BGS and data archived in numerous public databases. Scientific papers will have a target date of $2.5 \mathrm{yr}$

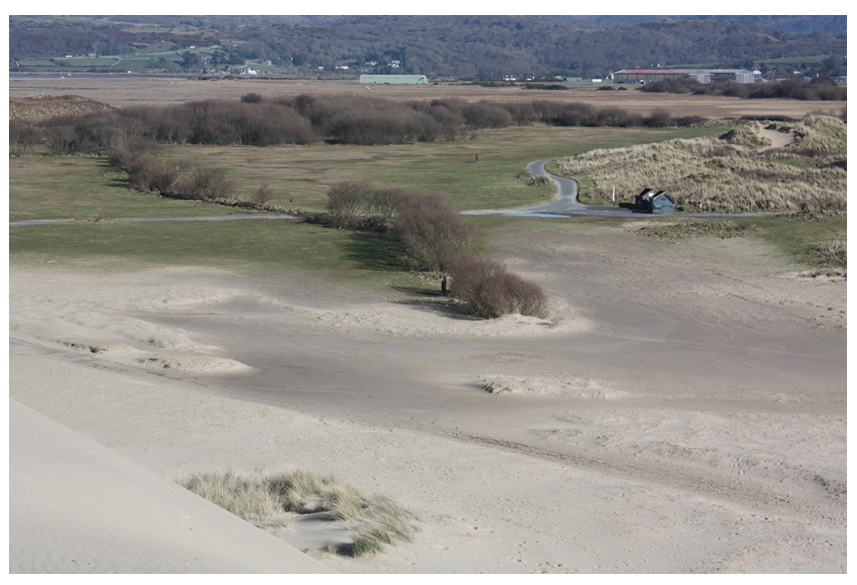

Figure 8. View from close to the first Mochras borehole site (now under sand dunes) looking NE towards the disused airfield at Llanbedr.

after a scientific results meeting (October 2018) in an online, open access journal.

\section{Summary and next steps}

In summary, the workshop highlighted the following unique potential for the Mochras project:

- First biostratigraphically calibrated magnetostratigraphy for the entire 25 Myr-long Early Jurassic based on a single section.

- High-resolution continuous cyclostratigraphy for the Early Jurassic; Astronomical Time Scale (ATS); Solar System resonance; length-of-day and tidal dissipation.

- Multi-proxy chemostratigraphy to track supercontinent breakup influence on the global earth system.

- Record of the Triassic/Jurassic mass extinction and subsequent recovery of the carbon cycle, biosphere and ocean, and effects from $\mathrm{CO}_{2}$ and other volatile releases from the CAMP.

- Early Jurassic sea level change and the icehousegreenhouse transition across the PliensbachianToarcian boundary.

- Interdependencies among primary productivity, microbial metabolisms, nutrient fluxes and ocean redox state.

- Integrated record of changes in atmospheric and marine composition understood in the context of quantitative whole earth system models.

- Order of magnitude improvement in knowledge of Early Jurassic geological timescale through full synthesis of radioisotopic and chonostratigraphic scales. 
The workshop identified the crucial next steps as preparation of the full ICDP proposal to be submitted in January 2014 , with a parallel programme of site geophysical characterization to guide precise location of the new borehole.

\section{The Mochras Revisited Science Team}

H. Abels, C. Belcher, J. Blau, J. Browning, J. Cartwright, D. Condon, S. Daines, S. Damborenea, A. Dickson, A. Fraguas, F. Hilgen, J. Hooker, C. Huang, S. Huesing, H. Jenkyns, C. Korte, W. Krijgsman, T. Lenton, C. Little, M. Manceñido, E. Mattioli, C. Meister, R. Morgan, R. Newton, J. Pálfy, G. Pienkowski, S. Poulton, A. Riccardi, A. Robinson, M. Ruhl, G. Suan, N. Smith, N. Thibault, C. Ullmann, P. Wignall, K. Williford, T. Wonik, and W. Xu

Acknowledgements. We would like to thank the British Geological Survey and in particular Scott Renshaw, for facilitating access to the core store at Keyworth. Charlotte Sweeny and Lisa Makros provided essential administrative support in Oxford. We thank John Geissman and Ulrich Harms for critical appraisal of the draft manuscript. Information in Figs. 2-4 is reproduced with permission from the British Geological Survey.

Edited by: U. Harms

Reviewed by: T. Wonik and J. W. Geissman

\section{References}

Allison, P. A., Hesselbo, S. P., and Brett, C. E.: Methane seeps on an Early Jurassic dysoxic seafloor, Palaeogeogr. Palaeocl., 270, 230-238, 2008.

Anbar, A. D. and Gordon, G. W.: Redox renaissance, Geology, 36, 271-272, 2008.

Belcher, C. M. and McElwain, J. C.: Limits on combustion in low $\mathrm{O}_{2}$ redefine palaeoatmospheric levels for the Mesozoic, Science, 321, 1197-1200, 2008.

Bjerrum, C. J. and Canfield, D. E.: Towards a quantitative understanding of the late Neoproterozoic carbon cycle, P. Natl. Acad. Sci. USA, 108, 5542-5547, 2011,

Bjerrum, C. J., Surlyk, F., Callomon, J. H., and Slingerland, R. L.: Numerical Paleoceanographic study of the Early Jurassic transcontinental Laurasian Seaway, Paleoceanography, 16, 390404, 2001.

Bjerrum, C. J., Bendtsen, J., and Legarth, J. J. F.: Modeling organic carbon burial during sea level rises with reference to the Cretaceous, Geochem. Geophy. Geosy., 7, 1-24, 2006.

Boomer, I. D. and Whatley, R.: Ostracoda and dysaerobia in the Lower Jurassic of Wales: the reconstruction of past oxygen levels, Palaeogeogr. Palaeocl., 99, 373-379, 1992.

Copestake, P. and Johnson, B.: Lower Jurassic (Hettangian, Toarcian) Foraminifera from the Mochras Borehole, North Wales (UK) and their application to a worldwide biozonation, Benthos, 83, 2nd Int. Symp. Benthic Foraminifera (Pau, April 1983), 183184, 1984.

Coward, M. P., Dewey, J. F., Hempton, M., and Holroyd, J.: Tectonic Evolution, in: The Millennium Atlas: Petroleum Geology of the
Central and Northern North Sea, edited by: Evans, D., Graham, C., Armour, A., and Bathurst, P., London, The Geological Society, 17-33. 2003.

Dera, G., Pellenard, P., Neige, P., Deconinck, J.-F., Puceat, E., and Dommergues, J.-L.: Distribution of clay minerals in Early Jurassic Peritethyan seas. Palaeoclimatic significance inferred from multiproxy comparisons, Palaeogeogr. Palaeocl., 271, 3951, 2009.

Dobson, M. R. and Whittington, R. J.: The geology of Cardigan Bay, Proceedings of the Geologists' Association, 98, 331-353, 1987.

Fraguas, A., Comas-Rengifo, M. J., Gómez, J. J., and Goy, A.: The calcareous nannofossil crisis in Northern Spain (Asturias province) linked to the Early Toarcian warming-driven mass extinction, Mar. Micropaleontol., 94-95, 58-71, 2012.

Gill, B. C., Lyons, T. W., and Jenkyns, H. C.: A global perturbation in the sulfur cycle during the Toarcian Oceanic Anoxic Event, Earth Planet. Sc. Lett., 312, 484-496, 2011.

Handoh, I. C. and Lenton, T. M.: Periodic mid-Cretaceous oceanic anoxic events linked by oscillations of the phosphorus and oxygen biogeochemical cycles, Global Biogeochem. Cy., 17, 1092, doi:10.1029/2003GB002039, 2003.

Hesselbo, S. P. and Jenkyns, H. C.: British Lower Jurassic sequence stratigraphy, in: Mesozoic-Cenozoic Sequence Stratigraphy of European Basins, edited by: de Graciansky, P. C., Hardenbol, J., Jacquin, T., Farley, M., and Vail, P. R., Special Publication of the Society for Sedimentary Geology (SEPM), 60, 561-581, 1998.

Hesselbo, S. P. and Pienkowski, G.: Stepwise atmospheric carbonisotope excursion during the Toarcian Oceanic Anoxic Event (Early Jurassic, Polish Basin), Earth Planet. Sc. Lett., 301, 365372, 2011.

Hesselbo, S. P., Gröcke, D. R., Jenkyns, H. C., Bjerrum, C. J., Farrimond, P. L., Morgans-Bell, H. S., and Green, O.: Massive dissociation of gas hydrates during a Jurassic Oceanic Anoxic Event, Nature, 406, 392-395, 2000.

Hesselbo, S. P., Deconinck, J.-F., Huggett, J. M., and Morgans-Bell, H. S.: Late Jurassic palaeoclimatic change from clay mineralogy and gamma-ray spectrometry of the Kimmeridge Clay, Dorset, UK, J. Geol. Soc. London, 166, 1123-1134, 2009.

Holford, S. P., Green, P. F., and Turner, J. P.: Palaeothermal and compaction studies in the Mochras borehole (NW Wales) reveal early Cretaceous and Neogene exhumation and argue against regional Palaeogene uplift in the southern Irish Sea, J. Geol. Soc. London, 162, 829-840, 2005.

Huang, C., Hesselbo, S. P., and Hinnov, L. A.: Astrochronology of the Late Jurassic Kimmeridge Clay (Dorset, England) and implications for Earth system processes, Earth Planet. Sc. Lett., 289, 242-255, 2010.

Jenkyns, H. C.: Geochemistry of Oceanic Anoxic Events, Geochem. Geophy. Geosy., 11, Q03004, doi:10.1029/2009GC002788, 2010.

Johnson, B.: Upper Domerian and Toarcian Foraminifera from the Llanbedr (Mochras Farm) Borehole, North Wales, Unpublished Ph.D. thesis, Univ. Coll. of Wales, Aberystwyth, 1975.

Johnson, B.: Ecological ranges of selected Toarcian and Domerian (Jurassic) foraminiferal species from Wales. 1st International Symposium on Benthonic Foraminifera of Continental Margins Part B: Palaeoecology and Biostratigraphy Maritime Sediments, Special Publication, 1, 545-556, 1976. 
Katz, M. E., Wright, J. D., Miller, K. G., Cramer, B. S., Fennel, K., and Falkowski, P. G.: Biological overprint of the geological carbon cycle, Mar. Geol., 217, 323-338, 2005.

Korte, C. and Hesselbo, S. P.: Shallow-marine carbon- and oxygenisotope and elemental records indicate icehouse-greenhouse cycles during the Early Jurassic, Paleoceanography, 26, PA4219, doi:10.1029/2011PA002160, 2011.

März, C., Poulton, S. W., Beckmann, B., Küster, K., Wagner, T., and Kasten, S.: Redox sensitivity of $\mathrm{P}$ cycling during marine black shale formation: Dynamics of sulfidic and anoxic, nonsulfidic bottom waters. Geochim. Cosmochim. Ac., 72, 37033717, 2008.

McArthur, J. M., Algeo, T. J., van de Schootbrugge, B., Li, Q., and Howarth, R. J.: Basinal restriction, black shales, and the Early Toarcian (Jurassic) oceanic anoxic event, Paleoceanography, 23, PA4217, doi:10.1029/2008PA001607, 2008.

Meister, C., Aberhan, M., Blau, J., Dommergues, J.-L., Feistburkhardt, S., Hailwood, E. A., Hart, M., Hesselbo, S. P., Hounslow, M. H., Hylton, M., Morton, N., Page, K., and Price, G.: The Global Boundary Stratotype Section and Point (GSSP) for the base of the Pliensbachian Stage (Lower Jurassic), Wine Haven, Yorkshire, UK, Episodes, 29, 93-106, 2006.

Meyers, S. R., Sierwert, S. E., Singer, B. S., Sageman, B. B., Condon, D. J., Obradovich, J. D., Jicha, B. R., and Sawyer, D. A.: Intercalibration of radioisotopic and astrochronologic time scales for the Cenomanian-Turonian boundary interval, Western Interior Basin, USA, Geology, 40, 7-10, 2012.

Muller, F. L.: The Paleoecology of the Liassic Benthic Foraminifera of Great Britain, Ph.D. dissertation, Rutgers University, New Brunswick, NJ, USA, 1990.

Newton, R. J., Pevitt, E. L., Wignall, P. B., and Bottrell, S. H.: Large shifts in the isotopic composition of seawater sulphate across the Permo-Triassic boundary in northern Italy, Earth Planet. Sc. Lett., 218, 331-345, 2004.

Newton, R. J., Reeves, E. P., Kafousia, N., Wignall, P. B., Bottrell, S. H., and Sha, J. G.: Low marine sulfate concentrations and the isolation of the European epicontinental sea during the Early Jurassic, Geology, 39, 7-10, 2011.

Olsen, P. E. and Kent, D. V.: Long-period Milankovitch cycles from the Late Triassic and Early Jurassic of eastern North America and their implications for the calibration of the early Mesozoic time scale and the long-term behaviour of the planets, Transactions of the Royal Society of London, Series A, 357, 1761-1787, 1999.

Pancost, R. D. and Boot, C. S.: The palaeoclimatic utility of terrestrial biomarkers in marine sediments, Mar. Chem., 92, 239-261, 2004.

Pieńkowski, G.: The epicontinental Lower Jurassic of Poland, Pol. Geol. Inst. Spec. Pap., 12, 1-154, 2004.

Poulton, S. W. and Canfield, D. E.: Development of a sequential extraction procedure for iron: implications for iron partitioning in continentally derived particulates, Chem. Geol., 214, 209-221, 2005.

Pearce, C. R., Cohen, A. S., Coe, A. L., and Burton, K. W.: Molybdenum isotope evidence for global ocean anoxia coupled with perturbations to the carbon cycle during the Early Jurassic, Geology, 36, 231-234, 2008.

Poulton, S. W. and Canfield, D. E.: Co-diagenesis of iron and phosphorus in hydrothermal sediments from the southern East Pacific Rise: Implications for the evaluation of paleoseawater phosphate concentrations, Geochim. Cosmochim. Ac., 70, 58835898, 2006.

Price, G. D.: The evidence and implications of polar ice during the Mesozoic, Earth-Sci. Rev., 48, 183-210, 1999.

Riding, J. B., Leng, M. J., Kender, S., Hesselbo, S. P., and Feist-Burkhardt, S.: Isotopic and palynological evidence for a new Early Jurassic environmental perturbation, Palaeogeogr. Palaeocl., 374, 16-27, 2013.

Ruhl, M., Deenen, M. H. L., Abels, H. A., Bonis, N. R., Krijgsman, W., and Kürschner, W. M.: Astronomical constraints on the duration of the early Jurassic Hettangian stage and recovery rates following the end-Triassic mass extinction (St Audrie's Bay/East Quantoxhead, UK), Earth Planet. Sc. Lett., 295, 262-276, 2010.

Sadler, P. M., Kemple, W. G., and Kooser, M. A.: CONOP9 programs for solving the stratigraphic correlation and seriation problems as constrained optimization, in: High Resolution Stratigraphic Approaches in Paleontology, edited by: Harries, P., Plenum Press, Topics in Geobiology, 21, 461-465, 2003.

Svensen, H., Corfu, F., Polteau, S., Hammer, Ø., and Planke, S.: Rapid magma emplacement in the Karoo Large Igneous Province, Earth Planet. Sc. Lett., 325-326, 1-9, 2012.

Tappin, D. R, Chadwick, R. A, Jackson, A. A., Wingfield, R. T. R., and Smith, N. J. P.: Geology of Cardigan Bay and the Bristol Channel, United Kingdom Offshore Regional Report, British Geological Survey, HMSO, 107 pp., 1994.

Van Buchem, F. S. P., McCave, I. N., and Weedon, G. P.: Orbitally induced small-scale cyclicity in a siliciclastic epicontinental setting (Lower Lias, Yorkshire, UK), in: Orbital Forcing and Cyclic Sequences, Special Publication of the International Association of Sedimentologists, edited by: de Boer, P. L. and Smith, D. G., 345-366, 1994.

van de Schootbrugge, B., Bailey, T. R., Katz, M. E., Wright, J. D., Rosenthal, Y., Feist-Burkhardt, S., and Falkowski, P. G.: Early Jurassic climate change and the radiation of organic walled phytoplankton in the Tethys Sea, Paleobiology, 31, 73-97, 2005.

van de Schootbrugge, B., Harazim, D., Sorichter, K., Oschmann, W., Fiebig, J., Püttmann, W., Peinl, M., Zanella, F., Teichert, B. M. A., Hoffmann, J., Stadnitskaia, A., and Rosenthal, Y.: The enigmatic ichnofossil Tisoa siphonalis and widespread authigenic seep carbonate formation during the Late Pliensbachian in southern France, Biogeosciences, 7, 3123-3138, doi:10.5194/bg7-3123-2010, 2010.

Weedon, G. P. and Jenkyns, H. C.: Cyclostratigraphy and the Early Jurassic time scale: data from the Belemnite Marls, Dorset, southern England, Bull. Geol. Soc. Am., 111, 1823-1840, 1999.

Wignall, P. B. and Newton, R.: Pyrite framboid diameter as a measure of oxygen deficiency in ancient mudrocks, Am. J. Sci., 298, 537-552, 1998.

Williams, C. J., Hesselbo, S. P., Jenkyns, H. C., and Morgans-Bell, H. S.: Quartz silt in mudrocks as a key to sequence stratigraphy (Kimmeridge Clay Formation, Late Jurassic, Wessex Basin, UK), Terra Nova, 13, 449-455, 2001.

Woodland, A. W. (Ed.): The Llanbedr (Mochras Farm) Borehole, Report No. 71/18, Institute of Geological Sciences, 115 pp., 1971. 